\title{
An update to measuring chronic illness, ir impairment and disability in national data sources
}

antmente

Office for National Statistics

This article reports progress in delivering a revision to survey questions on disability for implementation carrying out in 2010. The Office for National Statistics has relied on survey data to report and update annual estimates of disability-free life expectancy at national level. The survey question used in this calculation has remained consistent since 1972. However, changes in national legislation, a forthcoming European regulation and a number of inadequacies in the level of detail and consistency of disability data collected in household surveys (raised as part of the Review of Equality Data), will require its modification and extension to ensure survey data better reflect the growing data needs in the subject area of disability in the 21st Century.

The accurate and reliable measurement of disability is increasing in importance following the revision to the Disability Discrimination Act in 2005 and the publication of a strategy to improve the life chances of disabled people. Of particular concern is the lack of data on impairment types and how impairments interact with social barriers erected by society and its institutions, leading to, or intensifying, the level of disability experienced by people with impairment or limiting illnesses.

\section{Background}

The Office for National Statistics (ONS) led Review of Equality Data $^{1}$ was guided by a cross-government task force with members assembled from eight Whitehall departments and the three devolved administrations. The Review's findings were reported in October 2007, and included a detailed assessment of current data needs and a framework (Figure 1) for meeting these needs to enable statutory bodies to monitor the fairness of Britain across a number of equality strands, including disability.

The Review emphasised the inability to present a complete picture of inequality across all equality strands due to the inadequacy of available data, which was linked to a lack of strategic co-ordination between organisations involved in gathering and disseminating data. A number of recommendations were advanced to improve data co-ordination, comparability, quality, accessibility and presentation, and in addition to implementing a principled approach (Box One) to its collection and propagation. ${ }^{1}$

In response to these recommendations, ONS, together with the Office for Disability Issues (ODI), the Government Equalities Office (GEO), the devolved administrations and the National Statistics Harmonisation Group initiated a project aiming to deliver coherent statistics on the subject of disability through the development of harmonised questions and data collection standards in the future capture of disability data in national household surveys and administrative data sources. 

\begin{tabular}{l|l} 
Figure 1 & $\begin{array}{l}\text { The measurement framework proposed by the Centre for Analysis of Social Exclusion (2006) and endorsed by the Review of } \\
\text { Equality Data (Cabinet Office 2007) }\end{array}$
\end{tabular}

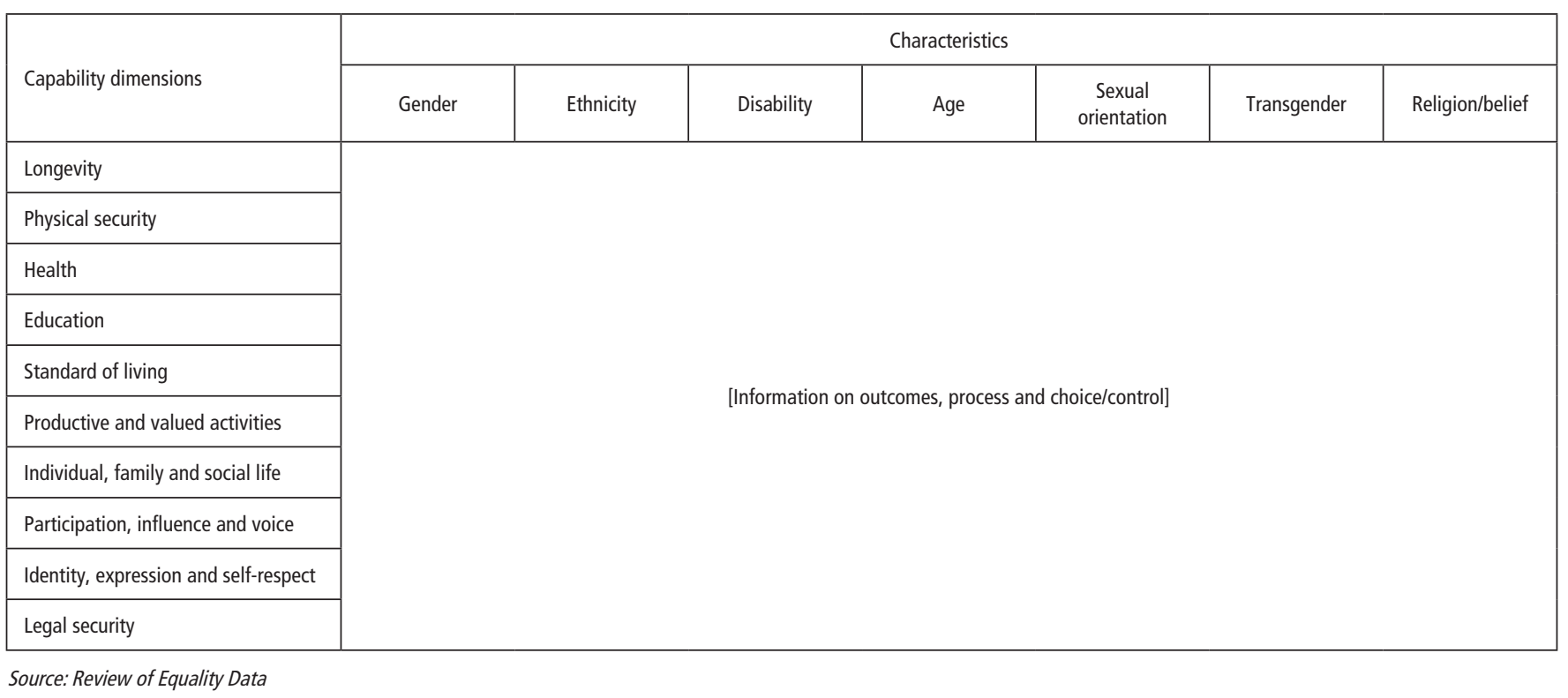

\section{Box one}

\section{The principles for collection and dissemination of equality data}

- Relevance

- Integrity

- Quality

- Accessibility

- Confidentiality

- Balancing the needs of users and the burden on suppliers

- Integration, accumulation and innovation

- Balancing efficiency and fairness

The disadvantages experienced by disabled people and the associated economic and social costs were highlighted in the government document 'Improving the Life Chances of Disabled People' published in 2005 by the Prime Minister's Strategy Unit. ${ }^{2}$ This report set an ambitious vision: by 2025 , disabled people in Britain should have full opportunities and choices to improve their quality of life and will be respected and included as equal members of society.

A package of measures designed to extend choice, reduce social exclusion and improve opportunities for independent living and participation in the labour market was approved by Government; the ODI was established to implement these measures and report progress annually. One of the key problems identified in this report, ${ }^{2}$ and echoed two years later in the Review of Equality Data, ${ }^{1}$ was the limitations of existing survey data to reliably measure: the number of disabled people generally; the transitions into and out of disability and within disability at key stages such as childhood to adulthood; the meaningful segregation by impairment type; and participation in mainstream activities such as education and employment. The ODI, in response to these identified data inadequacies, commissioned the Life Opportunities Survey of Great Britain (LOS) ${ }^{3}$ to extend the evidence base and build a measurement framework encompassing indicators of progress towards equality for disabled people by 2025 . Initially the survey will collect data on a baseline random sample of 50,000 people living in private households, and is expected to go live in the latter half of 2009; interim findings are expected during the summer of 2010 and final results reported in 2011.

While the data from LOS will add detail to the traditional, narrowly focused, data on disability currently available, there is recognition among national and European government bodies that existing sources have deficiencies in meeting their changing data needs and require urgent revision.

This article sets the context for:

- change to existing disability data sources

- the circumstances of current data collections and their limitations

- the stakeholder engagement process on disability definition and assessment of data needs

- a vision statement of what data will be collected by 2010

- an explanation of the composition of the revised question suite and its analysis potential, and

- our intentions for testing its fitness for use during 2009 


\section{Why measure disability}

Disabled people sometimes have additional needs to enable them to participate in society as fully as they would like and to live the sort of life they desire and aspire to. Often there are actions that government and voluntary organisations can take to provide disabled people with equality of opportunity to realise their potential: for example, through housing and transport adaptations, employment schemes, income benefits, and the provision of care services. These types of interventions, in terms of quantity and form, require knowledge of the range and density of needs at national and subnational population level, and how they evolve in order to set and adapt priorities and review progress over time.

Disability is a concern for most developed jurisdictions; both the World Health Organisation and the European Union (EU) have developed structural indicators on the subject of disability for undertaking cross-national comparisons to highlight the presence of inequalities in disability between nations. The valid and reliable reporting of these indicators requires a greater commitment to harmonisation of disability data across nation states.

Nationally, the extension to the Disability Discrimination Act (DDA) in 2005 included the introduction of a Disability Equality Duty (DED), which requires all public bodies to promote equality of opportunity for disabled people when developing policies, introducing practices and procedures and implementing a Disability Equality Scheme (DES). The DES is a framework to assist authorities in planning, delivering, evaluating and reporting on their activities to ensure compliance with the general DED. Two fundamental measures of any scheme will be: an enumeration of the number and proportion of disabled people the public body employs; and the number of economically active disabled people who are seeking work among the population the body serves. These indicators, among others, will set a benchmark against which the effectiveness of a DES can be judged.

Impairments can also be a cause of work limitation, restricting the type and amount of work an individual can undertake, as well as participation in the labour market. Employment is a key requirement for financial independence and independent living, as well as making provision for life beyond the state pension age. Measurement of the proportion of economically active people seeking work who have an impairment or chronic illness, and the economically inactive of working age on grounds of ill-health or impairment, are important for informing the present and future provision of state benefits. There is also the need to measure the proportion of the population beyond current state pension age who are fit for work, as the Government seeks to realign the state pension age with improvements in life expectancy that have occurred, and are expected to persist over the coming decades.

The demographic structure of the UK has been undergoing prominent transition since the 1970s with marked increases in life expectancy and the size of the population over the state pension age. A key concern among policy makers is the impact an ageing population has on the number of disabled people, with three possible scenarios: the growth in life expectancy exceeds the growth in health expectancy causing a sharp increase in the number of disabled people; the growth in life expectancy is matched by the growth in health expectancy leading to equilibrium; the growth in health expectancy exceeds the growth in life expectancy causing a contraction in the number of disabled people. The routine, valid and reliable reporting of the interaction between these indicators, broken down by severity level and impairment type for national and subnational populations, is currently unavailable from existing survey data sources and plugging this gap is an urgent priority.

\section{Definition of disability}

Disability is a multi-dimensional, and often dynamic, concept which presents measurement challenges. Perceptions of disability among the general population are diverse, and within the 'disabled' population no clear consensus on what constitutes disability exists. At the root of the confusion is the controversy surrounding the source of the disability: is it simply a function of impairment or disease, or the result of physical and social barriers erected by society and their interaction with impairment, or a combination of both? In the context of survey data, the terminology used in questions, the range of detail feasible and the particular data need it seeks to serve have an important influence on the measurement of disability: most surveys of a general nature have insufficient scope to collect the breadth of data necessary to take adequate account of the dimensions of disability involved, and compromises are made on the level of detail included.

Among the general public, the word 'disability' is widely perceived as synonymous with the permanent limitations associated with physical or mental impairment or chronic illness: a perception which conforms to a medical model of disability (Box Two). ${ }^{4}$

\section{Box two}

\section{Models of disability}

Medical model - disabled people are defined by their impairment or health condition, which is perceived as causing dependence and a need for treatment or care. The consequence is that constraints are placed on independent living and special arrangements imposed on access to benefits, housing, education, leisure and employment.

Social model - disability is caused by society: the physical, organisational and attitudinal barriers created by society, either deliberately or accidentally, compromise the ability of a person with impairment(s) or illness(es) to live independently and have the opportunity to participate in educational, employment and leisure activities.

The medical model promotes the view of a disabled person as dependent and needing to be either cured or supported: it justifies the way in which disabled people are socially excluded on grounds that their condition requires special intervention. However, the Prime Minister's Strategy Unit in $2005^{2}$ clarified the differences between the terms impairment and disability: impairment is defined as a loss of actual attributes of a person, whether in terms of limbs, organs or mechanisms, including psychological functioning; disability refers to the restrictions caused by society when it does not give equivalent attention and accommodation to the needs of individuals with impairments. These disadvantages experienced by an individual resulting from barriers to independent living, education, employment and other opportunities are representative of the social model of disability. A 'disabled person' under the social $\operatorname{model}^{5}$ can be described as someone who is disadvantaged by the way the wider environment interacts with their impairment or ill-health. 


\begin{tabular}{l}
\hline Definition of disability \\
\hline Adult population with rights under the Disability \\
Discrimination Act (DDA) 2005
\end{tabular}
Description (case definition)
A person who meets at least one of the following criteria:
- has or has had, a physical or mental impairment that has lasted, or is expected to last, for at least 12 months, which has, or had, a substantial and long-term adverse effect on the persons ability to carry out normal day-to-day activities, AND/OR
- has been diagnosed with HIV, multiple sclerosis or cancer, OR
- has a condition or impairment which would have a substantial long-term adverse effect on normal day-to-day activities without taking medication

Work limiting disability (WLD) among those of working age and those of state pension age seeking work

People of working age with a long-term disability (LTD)

Disabled adult population defined by the conventional limiting long-standing illness (LLSI), disability or infirmity questions

International Classification of Impairments, Disabilities and Handicaps (ICIDH), ${ }^{7}$ replaced in 2001 by the International Classification of Functioning, Disability and Health ${ }^{8}$

EU-Statistics on Income and Living Conditions Minimum European Health Module Global Activity Limitation indicator ${ }^{9}$
A long-term health problem that affects the amount, or kind, of work a person can do

This definition includes everyone with a WLD and/or a disability covered by the DDA 1995

Labour Force Survey (LFS) derived Annual Population Survey (APS)

LFS, derived APS

An illness, disability or infirmity that is long-standing and has troubled someone over a period of General Household Survey, time and limits activities in any way either strongly or not strongly Continuous Household Survey of Northern Ireland, Health Survey for England (HSE)
An objective measure of loss of function in performing normal activities linked to a physical or mental impairment or condition

HSE Disability module 2001

A self-assessment of restriction in the activities people usually do that has lasted for at least six European Health Interview months, caused by any ongoing physical or mental health problem, illness, impairment or other Survey disability. The time frame relates to the activity restriction

Sources: Bajekal, Harries, Breman and Woodfield 2004; Eurostat 2007; Disability Discrimination Act 2005

\section{How definitions are measured and operationalised in surveys}

The Department for Work and Pensions (DWP) commissioned Review of Disability Estimates and Definitions (2004) found that UK surveys adopted one of five definitions of disability (Table 1$){ }^{6}$

These definitions remain largely unchanged, although some changes have arisen from the update to the DDA 2005. A further definition is used currently by Eurostat following harmonisation of the Minimum European Health Module (MEHM) disability question used in the Statistics on Income and Living Conditions (EU-SILC) data collections since 2004; specifically, a Global Activity Limitation Indicator (GALI) with a distinct timeframe and extent of limitation scale.

A review of survey data sources discovered a recurring pattern in the measurement of disabled people: specifically, the majority of surveys contained two core questions asking respondents whether they suffered from a long-standing illness or disability and whether their illness or disability limited their daily activities (for a list of data sources and the disability questions they hold, see Annex A). A measure of disability defined by the DDA 2005 is collected currently on the Family Resources Survey (FRS) and the ONS Opinions Survey. The Health Survey for England measured disability in accordance with the ICIDH in its disability module in 2001, while the Welsh Health Survey activity limitation question includes age-related limitations. In addition to continuous household surveys, the Census of England and Wales in 1991 and 2001 included a question capturing limiting long-term illness or disability status; the 2011 Census will also include a question on disability, although this question will have a three category response format which allows the extent of disability to be reported.

Some surveys go further than a standard question on functional health status, and elicit information on impairment types and capability deficits the disabled person experiences. This widening of the standard data pertaining to chronic illness and disability allows users of disability data to take account of the heterogeneous nature of the disabled population and plan a more responsive and diverse range of services for disabled people. However, a clear dichotomy is apparent in the collection of additional detail: some departments such as the Department for Innovation, Universities and Skills (DIUS) collect data on impairment type using a list; others such as the DWP in their FRS collect data on capabilities. The former is more medically focused while the latter focuses more on what the person with impairments is capable of undertaking, such as carrying or lifting objects.

Surveys have received criticism for predominantly defining and measuring disability according to the medical model: the general view advanced by expert researchers in the field of disability is that these questions are simply too focused on chronic illness and impairment and greater weight should be given to a wider concept of disability. ${ }^{10,11,12}$ The merits of extending the information base to include additional detail in the form of impairment breakdowns and capability restrictions was highlighted in a recent World Bank discussion paper ${ }^{13}$ and in a paper published by the former Disability Rights Commission. The latter paper offered guidance for acquiring evidence to inform action, suggesting the addition of a question to discern information on the respondent's impairment type (Box Three). ${ }^{14}$

There is currently no standardised timeframe for survey questions eliciting information on the presence of chronic illness or disability. For example, the question on long-standing illness and activity limitation, asked on ONS's General Household Survey (GHS) since 1972 (and now asked on the Integrated Household Survey (IHS) core module), does not define a precise timeframe but clarifies that the term 'long-standing' represents a 'period of time'. The Labour Force Survey (LFS), on the other hand, asks whether the survey respondent has experienced limitations in activities for more than 12 months, while the FRS uses a timeframe of at least 12 months, taking account of likely future disability, to comply with a definition of a disabled person under the Disability Discrimination Act 2005; and this timeframe has been adopted by the 2011 England and Wales Census for its planned question on disability. A further time variant exists within the EU-SILC MEHM to be collected in the European Health Interview Survey, which asks survey respondents whether they have been limited in activities people usually do for at least the past six months.

This terminology references the time period to past activity restriction rather than the duration of chronic illness or disability. 


\section{Box three}

\section{Disability Rights Commission guidance on disability data collection}

Please state the type of impairment which applies to you. People may experience more than one type of impairment, in which case you may indicate more than one. If none of the categories apply, please mark 'Other' and specify the type of impairment.

- Physical impairment, such as difficulty using your arms or mobility issues which means using a wheelchair or crutches

- Sensory impairment, such as being blind/having a serious visual impairment or being deaf/having a serious hearing impairment

- Mental health condition, such as depression or schizophrenia

- Learning disability/difficulty (such as Down's syndrome or dyslexia) or cognitive impairment (such as autistic spectrum disorder)

- Long-standing illness or health condition such as cancer, HIV, diabetes, chronic heart disease, or epilepsy

- Other (please specify)

Cognitive testing of the MEHM questions on chronic illness and disability found considerable inconsistency surrounding the time period with which respondents were basing their answer, which ranged from at least 6 months; over a year; 2 to 3 years; 4 to 5 years; 7 to 8 years or something you have had since childhood. ${ }^{15}$ While the MEHM GALI question refers to a past timeframe, qualitative field testing observed respondents to take the likely future duration into account. This suggests the threshold of what constitutes a long-standing limitation is specific to the individual.

A further variation is present in how the force of limitation is collected. The IHS in combination with the General Lifestyles module uses the breakdown 'strongly limited' and 'limited, but not strongly' to differentiate the extent of activity limitation. The EU-SILC Global Activity Limitation Indicator uses the categories 'severely limited' and 'limited, but not severely', while the 2011 Census of England and Wales is proposing to use the terms 'Yes, a lot' and 'Yes, a little'. The DDA has no force of limitation breakdown, but uses the term 'substantial' in the body of its question eliciting limitation of activities.

Because definitions of disability vary by survey source, there is no annual estimate of the number of disabled adults in the UK that is coherent and reliable, and from which population subsets can be derived, which meets the needs of disability organisations, policy makers, service providers and researchers. The problems associated with comparing estimates of disability prevalence using alternative definitions has been assessed in the DWP sponsored systematic review of survey sources published in $2003 .{ }^{6}$ The aspiration to harmonise the future collection of disability data in national household surveys and administrative sources by revision of existing question formulations is partly to overcome this confusion generated by the number of alternative estimates calculated. However, this approach is not designed to preclude organisations from applying additional definitions to meet specific, less mainstream data requirements.
Approaches to the collection of survey data also differ (Annex B Table A2). The majority of surveys collect data using a household-based face-to-face interview, although some use Computer Assisted Telephone Interviewing (CATI) and others use a postal questionnaire. In those surveys containing a list of impairments or capabilities, data are collected either through open text or predefined independent category lists. The mode of questioning is linked to the classification of disability that can be operationalised; for example, the use of showcards can influence both response rates and classification of a case to a standardised classification system such as the International Classification of Functioning, Disability and Health. ${ }^{8}$ Such variations in methodology undermine comparisons of estimates of disability derived from different data sources.

\section{The Integrated Household Survey core module}

The IHS is a new household survey data source covering the populations of England, Scotland and Wales. It aims to provide a harmonised, high quality dataset that is capable of delivering analytical outputs of core topics at national and subnational levels. The IHS is multi-modular containing a core set of questions which cover common concepts, such as sexual identity, occupation, household composition, income and ethnicity. The planned survey composition of the IHS is outlined in Box Four.

\section{Box four}

\section{Integrated Household Survey modules}

IHS core module

Labour Force Survey (derived Annual Population Survey)

General Lifestyle (formerly General Household Survey)

Opinions Survey (formerly ONS Omnibus Survey)

Expenditure and Food Survey (now called Living Costs and Food Survey)

Longitudinal Life Opportunities Survey

English Housing Survey

The IHS core module will deliver a greatly enhanced sample size compared with what is currently available, and bring advantages related to accuracy and precision through the application of an unclustered sample design. It is estimated that the IHS core module data release in 2011 will contain a sample of 345,000 individuals and the benefits of this source for reporting estimates of disability at a number of disaggregated levels cannot be over stated. For this reason, it is the preferred survey for implementing any revision to the questions on disability currently held on household surveys.

The enhanced sample of the IHS provides scope for producing reliable estimates of ill-health, disability and activity limitation at local authority level intercensally (that is, between censuses) through pooling of data. This opportunity for improving intelligence of service need at local level must be exploited, as the advantages of reliable and adequately precise within, and between, local area intercensal trends for service planning cannot be overemphasised. 


\section{Cross-government consultation}

An initial cross-government consultation was carried out in response to a specific recommendation in the Review of Equality Data requiring partnership working between ODI, ONS, GEO and the devolved administrations. ${ }^{1}$ The ODI hosted a workshop with government colleagues in February 2008 with three primary objectives: to agree a common approach to disability definition; to develop common methodologies for collecting data; and to formulate an approach to implementation across government surveys. A number of government departments participated at the workshop and their stated reasons for collecting data on disability were clear: to inform policy developments; to plan the provision of core disability services; and to provide a resource to enable them to respond to information requests. The range of views expressed on future data collection were collated and used to build a description of current circumstances and how the goal of disability data harmonisation can be achieved. The aim and objectives agreed for progression are shown in Box Five.

\section{Box five}

\section{Workshop on the review of equality data}

\section{Aim}

To meet the data needs of key stakeholders and deliver coherent national statistics on chronic illness, impairment and disability through the application of agreed harmonised standards for data collection in surveys and administrative sources.

\section{Objectives}

- Clarify existing and future national and European requirements from data, and reach a consensus on priorities

- Appraise the definitions of disability (current and planned), their coverage within surveys, and their capability for delivering essential and desirable breakdowns

- Develop a question suite to measure these definitions (and/or subsets), feasible for implementation within the IHS core, and identify testing needs

- Assess the capability of the developed question suite formulation to measure the needed definitions required to meet data needs through cognitive and quantitative testing

- Synchronise the results of testing and report recommendations in line with survey planning cycles, allowing recommendations to be considered, agreed and implemented

\section{Examination of data needs}

\section{Office for National Statistics}

ONS uses questions on chronic illness, disability and infirmity and associated activity limitation, currently asked on the IHS core module (previously asked on the GHS) and the Continuous Household Survey of Northern Ireland (CHS), to calculate national estimates of disability-free life expectancy (DFLE), supplemented with limiting long-term illness data in the communal establishment population of the UK from the 2001 Census. This indicator of time spent free of disability is a valued enhancement to life expectancy information, and informs policymakers of trends in morbidity rates, relevant to assess health and social care need and the provision of benefits. A trend in DFLE has now been established using revised methodology from 2001 for the UK and constituent countries, and changing the form of this question will cause a discontinuity in this series. While this is an inconvenient consequence of harmonisation, it can be mitigated by understanding and quantifying the relationship between the existing question set used in the construction of the indicator and the future harmonised question suite.

Estimates of DFLE have also been constructed for local authorities and electoral wards in England and Wales for 2001 using census data. A data need highlighted, and currently not realisable from existing historic sources, is to provide DFLE estimates for local authorities to complement the life expectancy estimates. Consequently, a question suite that delivers the prevalence of current disability in households which can be combined with the prevalence of disability within communal establishments derived from the census question is a key data need for ONS to continue the valid and reliable measurement of DFLE at a number of geographical levels.

ONS supplies data annually to Eurostat to meet Regulation (EC) No 1177/2003 concerning Community Statistics on Income and Living Conditions (EU-SILC). The sample size needed for the UK is 13,700 individuals aged 16 years and over nested within 7,500 households for cross-sectional feeds and 10,500 individuals nested within 5,750 households for longitudinal feeds. A key concern for ONS is whether SILC data needs can be derived from the revision to the disability question suite. This uncertainty will be investigated through quantitative testing.

\section{Office for Disability Issues and the Department for Work and Pensions}

All public bodies are required to meet their DED and as such have to take steps to ensure they have sufficient data to do so. Of key importance is the need for departments to be aware of the heterogeneity of disability, and therefore the importance of gathering data on type of impairment, functional limitations and social barriers, depending on the particular policy emphasis of specific departments. The capture of data that enables the relationship between type of impairment, type of functional limitation and type of social barriers is a fundamental requirement highlighted by the ODI.

There is also a need to gather information on disability among residents of communal establishments who are not covered in household surveys to provide intercensal estimates of DDA defined disability.

The DWP has a number of indicators relevant to disabled people under the Fairness and Opportunity for all Public Sector Agreements (PSA). For example, Indicator 2 of Delivery Agreement $8^{16}$ states:

A narrowing of the gap between the employment rates of the following disadvantaged groups and the overall rate: disabled people, lone parents, ethnic minorities, people aged 50 and over, the 15 per cent lowest qualified, those living in the most deprived local authority wards.

The density of fitness for work beyond the state pension age has also been suggested as a potential indicator to judge the merits of revision to the state pension age in line with increases in life expectancy.

\section{Department of Health}

The Department of Health has expressed interest in the provision of intercensal updates of DFLE at primary care organisation and local authority level, for breakdowns by 'Spearhead' status ${ }^{17}$ and by socio-economic position. The enhanced sample of the IHS has potential to meet these additional needs and update them intercensally, allowing progress to be measured and relative variations between organisations, authorities and socio-economic classes to be compared. 


\section{Government Equalities Office}

The GEO is responsible for the Government's overall strategy on equality across equality strands and is responsible for delivering the Equality PSA. ${ }^{18}$ The GEO needs robust estimates of the disabled population to inform their PSA indicators which cover discrimination and unfair treatment at work, engagement in public life, provision of public transport adaptations that promote and assist usage by disabled people, and overcoming the barriers to independent living.

\section{Devolved administrations and the Department for Communities and Local Government}

The devolved administrations of Scotland, Wales and Northern Ireland requested a standard to be established for the collection of information on illness, disability and activity limitation, for application in their national surveys, to undertake reliable comparative analyses between themselves and the UK average and England.

A key issue for local government is whether to harmonise their local surveys with the measurement of disability in the 2011 Census or national household surveys. Local authorities often rely on the census to rebase their estimates of disability and update through simulation and/or local postal surveys. For local authorities to effectively adapt their services for disabled people, to better reflect the population covered under the DDA 2005, the proposed census question on disability is likely to prove deficient; for example, there is a lack of detail on impairment type. However, the introduction of the IHS with its considerably increased sample has the scope to facilitate the provision of intercensal estimates for subnational populations, including local authorities, for monitoring purposes, as well as delivering greater detail in the range of data on disability collected. Consequently, the IHS constitutes a valid alternative data source for local agencies to rebase their estimates of disability among the private household population.

\section{European Union}

The EU Task Force on Health Expectancies publishes cross-country comparisons by EU member states using data collected from the MEHM. To ensure comparisons are valid and reliable, the EU has decided to include a small set of health expectancies among its European Community Health Indicators to provide synthetic measures of disability, chronic morbidity and perceived health. Therefore the MEHM - composed of three questions covering these dimensions - has been introduced into the EU-SILC to improve the comparability of health expectancies between countries. In addition, life expectancy without long-term activity limitation, based on the MEHM GALI question, was selected in 2004 to be one of the structural indicators for assessing the EU strategic goals (Lisbon strategy) under the name of 'Healthy Life Years'.

A distinctive characteristic of the MEHM disability question is the lack of linkage between chronic morbidity and activity restriction. Consequently, the definition of disability in MEHM refers to activity restriction, and this is measured with a GALI question asked of all survey respondents, regardless of chronic illness status. The timeframe used in the GALI is at least the past six months and refers to the activity limitation not the health condition or impairment. Both these characteristics diverge from the DDA 2005 question suite, and the existing IHS questions.

\section{Workshop on disability definitions and harmonisation}

This workshop took place in June 2008 and was attended by Welsh Assembly Government, The Scottish Government, Department for Children, Schools and Families, Department for Work and Pensions, Department for Communities and Local Government, Equality and
Human Rights Commission, Office for National Statistics and Office for Disability Issues.

The aim of this workshop was to progress recommendation 4.3 of the Review of Equality Data to develop an agreed suite of questions to be used on all surveys, thereby ensuring a consistent approach to disability data collection across government by 2010 which will reliably capture the population of disabled people in a way consistent with the review's principles, and meets inter-departmental and European data needs. Prior to the workshop an initial suite, jointly constructed by ONS and ODI and based on the identified data needs presented above, was circulated to focus discussions during the day. Attempts at reaching a consensus on precise question content proved challenging, but the guidelines in Box Six were endorsed.

\section{Box six}

\section{Recommendations following workshop on disability definitions and data harmonisation}

- Two core questions for inclusion on all surveys measuring the number of currently disabled people with rights under the DDA with type of impairment or health condition captured

- Another optional question, which can be included on surveys if required, will monitor disability by looking at the barriers faced by people with impairments or health conditions

- A 12 month time period should be the standard for the question suite as it links to the 2011 Census and DDA

- The extent of limitation should be captured and linked to the response categories in either MEHM or the census

- Impairment types should not be routed from the question eliciting adverse effects and limitations in activities to allow prevalence of impairments to be calculated

- The list of impairments should include a category capturing the conditions of HIV, multiple sclerosis and cancer, specifically identified in the DDA 2005

- A means to assess the mitigating effects of medication on the reporting of activity limitation should be explored in testing

- Additional people with potential rights under the DDA, such as those with past DDA disabilities, will be collected in an alternative source or module

- The reliability of proxy responses for children under 16 years and those with communication problems or learning disabilities should be tested

\section{The revised disability question suite and rationale}

The guidelines and priorities for question testing documented in Box Six were applied to question suite development, conditioned on the practicalities of implementation within the core module of the IHS. The final formulation put forwarded for testing is presented in Figure 2. The rationale for each component is shown in Box Seven. 
Q1a. Do you have any long-standing physical or mental health condition, impairment or disability that has lasted or is expected to last 12 months or more? Please include those that are due to old age 1. Yes

2. No
Q1b. Do you have any long-standing physical or mental health condition, impairment or disability that has lasted or is expected to last 12 months or more? Please include those that are due to old age 1. Yes

2. No

IF 1:

What is the nature of your physical or mental health condition, impairment or disability?

0 . Open text - code up to 6 replies
Q1c. Do you have any of the following long-standing physical or mental health conditions or impairments that have lasted or are expected to last 12 months or more? Select all that apply. Please include those that are due to old age SHOWCARD

1. Blindness, deafness or other communication impairment

2. Mobility impairment, such as difficulty walking

3. Learning difficulty or disability, such as Down's syndrome

4. Mental health condition, such as depression

5. HIV, multiple sclerosis or cancer

6. Other long-standing health condition or disability

7. None
Q2a. Are your day-to-day activities limited because of any physical or mental health condition, impairment or disability? Please include those that are due to old age. Would you say you are:

1. Severely limited

2. Limited but not severely

3. Not limited at all

IF $Q 2=1$ or 2

Q3. How long have your day-to-day activities been limited?

1. Less than 6 months

2. At least 6 months but less than 12 months

3. At least 12 months

IF 1 or 2 :

Do you expect your day-to-day activities to be limited for 12 months or more altogether?

1. Yes

2. No

IF 1 to Q1a or Q1b or 1 thru 6 to Q1C AND 2 or 3 to Q2:

Q4. Do you take any medication for your long-standing health condition(s) or disability(ies)?

1. Yes

2. No

IF 1:

If you did not have this medication, do you think your activities would be limited by your long-standing health condition(s) or disability(ies)?

1. Yes

2. No

If 1 would you be:

1. Severely limited (limited a lot); or

2. Limited but not severely (limited a little)

\section{IF Q1c $=1$ thru 6}

Q2b. Do your physical or mental health condition(s), impairment(s) or disability(ies) mean that your day-to-day activities are limited? Please include those that are due to old age. Would you say you are:

1. Limited a lot

2. Limited a little

3. Not limited at all

\section{Box seven}

\section{Rationale for question formulation}

- Question 1 versions establish the presence of conditions and impairments with open and prescribed breakdowns elicited in versions $b$ and $c$ respectively. The term disability is excluded from question $1 c$ to assess impact on prevalence

- Question 2 aims to establish the presence of limitations in day-to-day activities the respondent experiences: the questions differ in the strength of linkage of the condition or impairment with the limitation and in routeing; version $b$ is routed from Q1 while version $a$ is not. This violates the EU guidelines on non-routeing in the case of Q2b, but overcomes the social model objections to directly linking the terms impairments and disability, which implies disability is simply a function of impairment

- Question 3 aims to place the limitations in daily activities into a timeframe consistent with DDA and European data needs, 12 months or more in case of the DDA and for at least the past six months in the case of EU-SILC

- Question 4 asks the respondent whether s/he is taking medication for the condition(s) or impairment(s) and - if the answer to question 2 was category 3 - whether her/his daily activities would be limited without it
This suite was supplemented with two questions (Figure 3) on the social barriers faced by people with loss of functions as a result of impairment or illness. The rationale for the social barriers questions is to collect a high-level indicator of social model disability. These questions are an attempt to recognise that there is not necessarily a direct link between impairment and disability: an implicit assumption of questions $2 \mathrm{a}$ and $2 \mathrm{~b}$ above. Questions $5 \mathrm{a}$ and $5 \mathrm{~b}$ provide respondents with the opportunity to identify areas of normal life where they are limited, while questions $6 \mathrm{a}$ and $6 \mathrm{~b}$ attempt to provide some of the most common contextual factors which influence participation restrictions. Contextual factors include social/environmental factors such as poor services, as well as individual factors such as health conditions and it is the interaction between these factors which disable individuals.

The combined medical and social model question suite is based on the International Classification of Functioning, Disability and Health, ${ }^{8}$ which partitions disability into a series of components:

- Body functions and structures (for example, a defect in the structure of the ear) which is measured in questions $1 \mathrm{a}, 1 \mathrm{~b}$ and $1 \mathrm{c}$ capturing impairment and health conditions

- Difficulty with day-to-day activities as a result of the loss of function established in question 1 variants, broadly equivalent to question 2 variants

- Participation restrictions, such as difficulty finding employment, measured in questions $5 \mathrm{a}$ and $5 \mathrm{~b}$

- Contextual factors such as an absence of building, transport and workspaces adaptations measured in questions $6 \mathrm{a}$ and $6 \mathrm{~b}$ 


\section{$\begin{array}{ll}\text { Figure } 3 & \text { Social barriers question suite for testing }\end{array}$}

Q5a. There are many reasons why people can't take part in activities as much as they would like to. Are you limited in the following areas of life for any reason ...

Individual Prompt - Code all that apply

1. Education?

2. Work?

3. Transport?

4. Personal relationships?

5. Leisure?

6. None of these

If $Q 5 a=1$ thru 5

Q6a. SHOWCARD

Q6a What limits you in these areas?

Code all that apply

1. Financial reasons

2. Too busy/not enough time

3. A health condition, illness or impairment

4. A disability

5. Poor services

6. Lack of assistance or equipment

7. Badly designed buildings

8. Attitudes of others

9. Lack of information

10. Other reasons
Q5b. There are many reasons why people can't take part in activities as much as they would like to. Do you have any difficulty taking part in the following areas of life for any reason ...

Individual Prompt - Code all that apply

1. Education?

2. Work?

3. Transport?

4. Personal relationships?

5. Leisure?

6. None of these

If $Q 5 b=1$ thru 5

Q6b. SHOWCARD

Q6b What causes you difficulty in these areas?

Code all that apply

1. Financial reasons

2. Too busy/not enough time

3. A health condition, illness or impairment

4. A disability

5. Poor services

6. Lack of assistance or equipment

7. Badly designed buildings

8. Attitudes of others

9. Lack of information

10. Other reasons

\section{Future plans}

The changes to questions required to harmonise data across surveys present uncertainty about how they will be understood in the field and whether the wording, routeing and breadth of categorisation will validly and reliably define the target population. A project aiming to cognitively test the question suite was initiated in March 2009: the research is being conducted by the research organisation Independent Social Research and will report findings in June 2009. The research will encompass an in-depth exploration of how respondents understand and interpret the draft questions, their ability and willingness to answer them, and the adequacy of the pre-defined categories to identify the spectrum of impairments, limitations and barriers. The findings of the cognitive testing will then be presented to a range of users of disability statistics such as organisations for disabled people, government agencies and academia to gather views on the need for further adaptation of the question suite, and establish priorities for quantitative testing in the autumn. A future article will report the findings of testing and user consultation, and the plans for implementation of the question suite on the IHS in 2010.

\section{The potential of the disability question suite for extending ONS analyses}

ONS reports life expectancy at birth and at age 65 by local and unitary authorities in the UK on an annual basis. ${ }^{19}$ These estimates of longevity are valued by local government stakeholders for service planning, and they provide national governments with evidence of the scale of geographical inequalities in mortality. However, there is uncertainty about whether health expectancies are patterned in a similar way to life expectancy. While the decennial census provides the necessary data to undertake precise and accurate measurement of health expectancy for local authorities, ${ }^{20}$ there is only opportunity to update these figures every ten years, constraining the ability to monitor improvement and relative inequalities between areas during the intervening years: current survey data are inadequate for computing estimates of health expectancy at subnational levels. This gap in the evidence-base needed for planning and forecasting at local level was raised by the Department for Communities and Local Government during the consultation phase. Moreover, the Department of Health has expressed interest in the provision of health expectancies by Primary Care Organisations, to inform their service needs
The greatly enhanced sample size of the IHS core module will deliver adequate data to enable the routine measurement of health expectancies by local areas in Great Britain and health areas in England to be undertaken and reported annually alongside estimates of life expectancy.

The disaggregation of DFLE by severity level is another potential metric ONS will be able to deliver following the implementation of the question suite. The needs of individuals with severe limitations in carrying out day-to-day activities are different to those who are limited but not severely. The heterogeneity of the population classified as disabled is not reflected in the DFLE metric currently reported by ONS, and delivering metrics that distinguishes these groups will add value to service planning intelligence.

The scope to build the capability dimensions of the Review of Equality Data endorsed measurement framework into metrics of disability will be enhanced through use of the socio-demographic variables collected on the IHS core. For example, the scope to compare the educational achievement, general health, standard of living, participation in the labour market and the socio-economic class distribution of the disabled and non-disabled population will help to ascertain the presence of inequality and to monitor progression towards equality for disabled people by 2025

\section{Conclusion}

This article has described recent developments to revise the formulation and scope of disability data collection in the UK in response to the publication of the Review of Equality Data in 2007 and the expressed data needs of government departments. The revision to the disability question suite has been targeted for inclusion on the IHS core module: a new data source which benefits from a greatly enhanced sample size, capable of delivering a wider and more detailed compilation of policy relevant outputs than previously available.

Implementation of the question suite onto the IHS core module is planned for April 2010, depending on its performance during cognitive and quantitative testing. The 2010 deadline is desirable to enable a 3 -year aggregated sample of approximately one million individuals, centred on the census year, to be used as an alternative source for rebasing local area estimates of the number of disabled people. 
Formulation of the disability question suite has been guided by the expressed data needs of consulted government departments, taking into consideration stretched survey space allocations. The variation in timeframes, terminology and routeing, and the tensions between the relative merits of competing definitions of disability, has constrained the question suite formulation presented here. However, ONS believes this suite constitutes a balanced compromise, capable of meeting the majority of data needs expressed by government departments for the second decade of the 21 st Century. ONS will report the findings of the cognitive and quantitative testing projects and recommendations for action in a follow-up article in 2010.

\section{References}

1. Office for National Statistics (2007) Report from the review of equality data. Available on the Office for National Statistics website at: www.statistics.gov.uk/downloads/theme_social/EDR_Final.doc.pdf

2. Prime Minister's Strategy Unit (2005) Improving the Life Chances of Disabled People. Accessed 16 April 2009, available at: www.cabinetoffice.gov.uk/strategy/work_areas/disability.aspx

3. Office for Disability Issues (2008) Annual Report: Turning Equality into Reality. Accessed 16 April 2009, available at: www.officefordisability.gov.uk/research/annualreport.asp

4. Abberley P (1997) 'The Limits of Classical Social Theory in the Analysis and Transformation of Disablement', in Barton L and Oliver M (eds), Disability Studies: Past Present and Future, The Disability Press: Leeds.

5. Thomas C (2002) 'Disability Theory: Key Ideas, Issues and Thinkers’, in Barnes C, Oliver M and Barton L (eds) (2002), Disability Studies Today, Polity: Cambridge, 38-57.

6. Bajekal M, Harries T, Breman R and Woodfield K (2004) Review of Disability Estimates and Definitions, Her Majesty's Stationery Office: London.

7. World Health Organisation (1980) International Classification of Impairments, Disabilities and Handicaps, World Health Organisation: Geneva.

8. World Health Organisation (2001) International Classification of Functioning, Disability and Health, World Health Organisation: Geneva.

9. European Commission (2007) Harmonisation of SILC and EHIS questions on health: guidelines for the health in SILC from 2008 operation onwards, European Commission: Luxembourg.
10. Bricher G (2000) 'Disabled people, Health Professionals and the social model of disability: can there be a research relationship?', Disability and Society Vol 15, No. 5, 781-93.

11. Burchardt T (2004) 'Capabilities and Disability: the capabilities framework and the Social Model of Disability', Disability and Society Vol 19, No. 7, 735-51.

12. Barnes C and Mercer G (eds) (2004) Disability Policy and Practice: Applying the Social Model, Disability Press: Leeds.

13. World Bank (2007) Measuring Disability Prevalence, SP Discussion Paper No. 0706.

14. Disability Rights Commission (2007) The Disability Equality Duty: Guidance on gathering and analysing evidence to inform action. Accessed 16 April, available at: www.dotheduty.org/files/DRC_Evidence_Gathering_Guidance.pdf

15. Office for National Statistics (2005) Evaluation of modules for the European Health Interview Survey. Available on the Office for National Statistics website at: www.ons.gov.uk/about/who-we-are/our-services/data-collectionmethodology/reports-and-publications

16. Her Majesty's Treasury (2008) PSA Delivery Agreement 8: Maximise employment opportunity for all. Accessed 16 April 2009, available at: www.hm-treasury.gov.uk/d/pbr_csr07_psa8.pdf

17. Department of Health (2004) Tackling health inequalities: the Spearhead group of Local Authorities and Primary Care Trusts. Accessed 21 April 2009, available at: www.dh.gov.uk/en/Publicationsandstatistics/Publications/ PublicationsPolicyAndGuidance/DH_4101455

18. Government Equalities Office (2008) Delivering the Equality PSA 2008-2011. Accessed 16 April 2009, available at: www.equalities.gov.uk/PDF/7877-TSO-PSA_Delivery_Plan.pdf

19. Wells C and Gordon E (2008) 'Report: Life expectancy at birth and at age 65 by local areas in the United Kingdom, 2005-07', Health Statistics Quarterly, 40, 81-84. Available on the Office for National Statistics website at: www.statistics.gov.uk/statbase/Product.asp?vlnk=6725

20. Office for National Statistics (2006) 'Report: Health expectancies for local authorities in England and Wales, 2001', Health Statistics Quarterly, 32, 87-96. Available on the Office for National Statistics website at: www.statistics.gov.uk/statbase/Product.asp?vlnk=6725 
Annex A

\begin{tabular}{|c|c|c|c|c|c|c|c|c|c|c|}
\hline \multirow{3}{*}{ Core question type } & \multicolumn{9}{|c|}{ Data source } & \multirow[b]{2}{*}{$\begin{array}{l}\text { Dept. for } \\
\text { Works and } \\
\text { Pensions }\end{array}$} \\
\hline & $\begin{array}{l}\text { Dept. for } \\
\text { Culture, } \\
\text { Media and }\end{array}$ & $\begin{array}{l}\text { Dept. for } \\
\text { Transport }\end{array}$ & \multicolumn{2}{|c|}{$\begin{array}{l}\text { Dept for Communities and } \\
\text { Local Government }\end{array}$} & \multicolumn{4}{|c|}{ Dept. for Children, School and Families } & \multirow{2}{*}{$\begin{array}{c}\text { Dept. for } \\
\text { Business } \\
\text { Enterprise and } \\
\text { Regulatory } \\
\text { Reform } \\
\\
\text { Fair } \\
\text { Treatment at } \\
\text { Work }\end{array}$} & \\
\hline & $\begin{array}{l}\text { Taking Part } \\
\text { Survey }\end{array}$ & $\begin{array}{c}\text { National } \\
\text { Travel Survey }\end{array}$ & $\begin{array}{l}\text { English } \\
\text { Housing } \\
\text { Survey }\end{array}$ & $\begin{array}{l}\text { New Place } \\
\text { Survey }\end{array}$ & Pre 16 Survey & $\begin{array}{l}\text { Youth Cohort } \\
\text { Survey }\end{array}$ & $\begin{array}{l}\text { Longitudinal } \\
\text { Study of } \\
\text { Young People } \\
\text { in England }\end{array}$ & $\begin{array}{c}\text { Post } 16 \\
\text { National } \\
\text { Pupil } \\
\text { Database and } \\
\text { Individual } \\
\text { Learner } \\
\text { Record }\end{array}$ & & $\begin{array}{l}\text { Family } \\
\text { Resources } \\
\text { Survey }\end{array}$ \\
\hline $\begin{array}{l}\text { Do you (or any member in } \\
\text { your household) have any } \\
\text { long-standing illness, disability } \\
\text { or infirmity? }\end{array}$ & & $\begin{array}{l}\text { 'any disability } \\
\text { or other } \\
\text { long-standing } \\
\text { health } \\
\text { problem' }\end{array}$ & $\begin{array}{l}\text { For } \\
\text { household }\end{array}$ & & & & . & $\begin{array}{l}\text { Learner } \\
\text { considers him/ } \\
\text { herself to have } \\
\text { a learning } \\
\text { difficulty and/ } \\
\text { or disability } \\
\text { and/or health } \\
\text { problem }\end{array}$ & & $\begin{array}{l}\text { 'long- } \\
\text { standing } \\
\text { physical } \\
\text { or mental } \\
\text { impairment, } \\
\text { illness or } \\
\text { disability' }\end{array}$ \\
\hline $\begin{array}{l}\text { Does this illness or disability } \\
\text { limit your activities in any way? }\end{array}$ & & & & & & & $\begin{array}{l}\text { Compared } \\
\text { to people of } \\
\text { your age }\end{array}$ & & & \\
\hline $\begin{array}{l}\text { What type/sort of illness/ } \\
\text { impairment or disability do } \\
\text { you have? }\end{array}$ & & & $\begin{array}{l}\text { List of } \\
\text { options } \\
\text { offered }\end{array}$ & & & & & $\begin{array}{l}\text { List of } \\
\text { impairments } \\
\text { and, } \\
\text { separately, a } \\
\text { list of specific } \\
\text { learning } \\
\text { difficulties } \\
\text { offered }\end{array}$ & & \\
\hline $\begin{array}{l}\text { Do you receive medication } \\
\text { or treatment without which } \\
\text { your health problems would } \\
\text { substantially affect your life? }\end{array}$ & & & & & & & & & & \\
\hline $\begin{array}{l}\text { Have you ever had a long-term } \\
\text { illness, disability or infirmity } \\
\text { that affected your activities? }\end{array}$ & & & & & & & & & & $\begin{array}{l}\text { Along with } \\
\text { - did this } \\
\text { substantially } \\
\text { limit your } \\
\text { ability to } \\
\text { carry out } \\
\text { out normal } \\
\text { day-to-day } \\
\text { activities }\end{array}$ \\
\hline
\end{tabular}

\begin{tabular}{|c|c|c|c|c|c|c|c|c|c|}
\hline \multirow[b]{3}{*}{ Core question type } & \multicolumn{9}{|c|}{ Data source } \\
\hline & \multicolumn{3}{|c|}{ Scottish Government } & \multicolumn{3}{|c|}{ Northern Ireland } & \multicolumn{3}{|c|}{ Dept. of Innovation, Universities and Skills } \\
\hline & Health Survey & $\begin{array}{l}\text { All Forests } \\
\text { Visitor } \\
\text { Monitoring } \\
\text { Survey }\end{array}$ & $\begin{array}{l}\text { Scottish House } \\
\text { Condition } \\
\text { Survey }\end{array}$ & Census & $\begin{array}{l}\text { Continuous } \\
\text { Household } \\
\text { Survey }\end{array}$ & $\begin{array}{l}\text { Health } \\
\text { and Social } \\
\text { Wellbeing } \\
\text { Survey }\end{array}$ & $\begin{array}{l}\text { Student } \\
\text { Income and } \\
\text { Expenditure } \\
\text { Survey }\end{array}$ & $\begin{array}{l}\text { Universities } \\
\text { and Colleges } \\
\text { Admissions } \\
\text { System }\end{array}$ & $\begin{array}{l}\text { Higher } \\
\text { Education } \\
\text { Statistics } \\
\text { Agency }\end{array}$ \\
\hline $\begin{array}{l}\text { Do you (or any member in } \\
\text { your household) have any } \\
\text { long-standing illness, disability } \\
\text { or infirmity? }\end{array}$ & & $\begin{array}{l}\text { Do you have } \\
\text { a disability or } \\
\text { special need? }\end{array}$ & $\begin{array}{l}\text { Longer version } \\
\text { of question } \\
\text { used }\end{array}$ & & & & $\begin{array}{l}\text { Uses Disability } \\
\text { Students } \\
\text { Allowance as a } \\
\text { proxy measure }\end{array}$ & & $\begin{array}{l}\text { Uses Disability } \\
\text { Students } \\
\text { Allowance as a } \\
\text { proxy measure }\end{array}$ \\
\hline \multicolumn{10}{|l|}{$\begin{array}{l}\text { Does this illness or disability limit } \\
\text { your activities in any way? }\end{array}$} \\
\hline $\begin{array}{l}\text { What type/sort of illness/ } \\
\text { impairment or disability do you } \\
\text { have? }\end{array}$ & $\begin{array}{l}\text { What is the } \\
\text { matter with } \\
\text { you? }\end{array}$ & Options offered & $\begin{array}{l}\text { Which of the } \\
\text { conditions on } \\
\text { the list best } \\
\text { describe the } \\
\text { ill health or } \\
\text { disability? }\end{array}$ & & $\begin{array}{l}\text { Would you } \\
\text { mind telling } \\
\text { me what this } \\
\text { illness or } \\
\text { infirmity is? }\end{array}$ & $\begin{array}{l}\text { Would you } \\
\text { mind telling } \\
\text { me what this } \\
\text { illness or } \\
\text { infirmity is? }\end{array}$ & & $\begin{array}{l}\text { List of } \\
\text { impairments } \\
\text { offered for the } \\
\text { respondents to } \\
\text { identify with }\end{array}$ & $\begin{array}{l}\text { List of } \\
\text { impairments } \\
\text { offered for the } \\
\text { respondents to } \\
\text { identify with }\end{array}$ \\
\hline \multicolumn{10}{|l|}{$\begin{array}{l}\text { Do you receive medication } \\
\text { or treatment without which } \\
\text { your health problems would } \\
\text { substantially affect your life? }\end{array}$} \\
\hline $\begin{array}{l}\text { Have you ever had a long-term } \\
\text { illness, disability or infirmity that } \\
\text { affected your activities? }\end{array}$ & & & & & & & & & \\
\hline
\end{tabular}

Survey question used to determine disability status 


\begin{tabular}{|c|c|c|c|c|c|c|c|c|c|}
\hline \multirow{3}{*}{ Core question type } & \multicolumn{9}{|c|}{ Data source } \\
\hline & \multicolumn{3}{|c|}{ Welsh Assembly } & \multicolumn{4}{|c|}{ Office for National Statistics } & \multirow{2}{*}{ 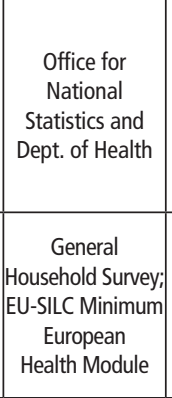 } & $\begin{array}{c}\text { Office for } \\
\text { National } \\
\text { Statistics } \\
\text { and Dept. for } \\
\text { Communities } \\
\text { and Local } \\
\text { Government }\end{array}$ \\
\hline & $\begin{array}{l}\text { Welsh Health } \\
\text { Survey }\end{array}$ & Living in Wales & $\begin{array}{l}\text { Future Skills } \\
\text { Wales }\end{array}$ & $\begin{array}{l}\text { Labour Force } \\
\text { Survey }\end{array}$ & $\begin{array}{l}\text { Integrated } \\
\text { Household } \\
\text { Survey and } \\
\text { Expenditure } \\
\text { and Food } \\
\text { Survey }\end{array}$ & $\begin{array}{l}\text { Opinions } \\
\text { Survey }\end{array}$ & $\begin{array}{l}\text { Household } \\
\text { Assets Survey }\end{array}$ & & $\begin{array}{l}\text { Survey of } \\
\text { English } \\
\text { Housing }\end{array}$ \\
\hline $\begin{array}{l}\text { Do you (or any member in your } \\
\text { household) have any } \\
\text { long-standing illness, disability } \\
\text { or infirmity? }\end{array}$ & & & & $\begin{array}{l}\text { Do you have } \\
\text { any health } \\
\text { problems or } \\
\text { disabilities } \\
\text { which limits the } \\
\text { amount or type } \\
\text { of work you } \\
\text { can do? }\end{array}$ & & & & & \\
\hline $\begin{array}{l}\text { Does this illness or disability limit } \\
\text { your activities in any way? }\end{array}$ & $\begin{array}{l}\text { Includes } \\
\text { illnesses and } \\
\text { disabilities and } \\
\text { due to old age }\end{array}$ & & & & & $\begin{array}{l}\text { Limit your } \\
\text { ability to carry } \\
\text { out out normal } \\
\text { day-to-day } \\
\text { activities? }\end{array}$ & & $\begin{array}{l}\text { Also } \\
\text { disaggregated } \\
\text { by limited or } \\
\text { strongly limited }\end{array}$ & \\
\hline $\begin{array}{l}\text { What type/sort of illness/ } \\
\text { impairment or disability do you } \\
\text { have? }\end{array}$ & & & & $\begin{array}{l}\text { Which of } \\
\text { these is your } \\
\text { main health } \\
\text { problem? }\end{array}$ & & & & $\begin{array}{l}\text { What is the } \\
\text { matter with } \\
\text { you? }\end{array}$ & \\
\hline $\begin{array}{l}\text { Do you receive medication } \\
\text { or treatment without which } \\
\text { your health problems would } \\
\text { substantially affect your life? }\end{array}$ & & & & $\begin{array}{l}\text { Relates } \\
\text { question to } \\
\text { limiting activity } \\
\text { question }\end{array}$ & & & & & \\
\hline $\begin{array}{l}\text { Have you ever had a long-term } \\
\text { illness, disability or infirmity that } \\
\text { affected your activities? }\end{array}$ & & & $\begin{array}{l}\text { Questions are } \\
\text { included on } \\
\text { employment, } \\
\text { training and } \\
\text { disability }\end{array}$ & & & $\begin{array}{l}\text { Along with } \\
\text { - did this } \\
\text { substantially } \\
\text { limit your } \\
\text { ability to carry } \\
\text { out out normal } \\
\text { day-to-day } \\
\text { activities }\end{array}$ & & & \\
\hline
\end{tabular}

Survey question used to determine disability status

Survey uses receipt of benefits as a proxy for disability status 


\section{Annex B}

\section{Table A1}

Timeframes covered by surveys

\begin{tabular}{|c|c|c|c|}
\hline Period of time & At least 12 months & More than a year & At least 6 months \\
\hline $\begin{array}{l}\text { Office for National Statistics - Integrated Household } \\
\text { Survey }\end{array}$ & $\begin{array}{l}\text { Department for Work and Pensions - Family } \\
\text { Resources Survey }\end{array}$ & $\begin{array}{l}\text { Office for National Statistics - Labour } \\
\text { Force Survey }\end{array}$ & $\begin{array}{l}\text { EU-SILC proposals for the General } \\
\text { Household Survey }\end{array}$ \\
\hline Office for National Statistics - Opinions Survey & $\begin{array}{l}\text { Department for Children, Schools and } \\
\text { Families - Longitudinal Study of Young } \\
\text { People in England }\end{array}$ & Welsh Assembly - Future Skills Wales & \\
\hline $\begin{array}{l}\text { Office for National Statistics - Household Assets } \\
\text { Survey }\end{array}$ & $\begin{array}{l}\text { Department for Communities and Local } \\
\text { Government - English Housing Survey }\end{array}$ & $\begin{array}{l}\text { Department for Business Enterprise and } \\
\text { Regulatory Reform - Fair Treatment } \\
\text { at Work }\end{array}$ & \\
\hline $\begin{array}{l}\text { Department for Children, Schools and Families and } \\
\text { Department for Innovation, Universities and Skills - } \\
\text { Youth Cohort Study }\end{array}$ & $\begin{array}{l}\text { Department for Transport - National Travel } \\
\text { Survey }\end{array}$ & & \\
\hline Welsh Assembly - Living in Wales & $\begin{array}{l}\text { Scottish Government - Scottish Health } \\
\text { Survey }\end{array}$ & & \\
\hline \multicolumn{4}{|l|}{$\begin{array}{l}\text { Department for Communities and Local Government - } \\
\text { English House Conditions Survey }\end{array}$} \\
\hline \multicolumn{4}{|l|}{$\begin{array}{l}\text { Department for Communities and Local Government - } \\
\text { New Place Survey }\end{array}$} \\
\hline \multicolumn{4}{|l|}{$\begin{array}{l}\text { Department for Culture, Media and Sport - Taking } \\
\text { Part }\end{array}$} \\
\hline $\begin{array}{l}\text { Scottish Government - Scottish House Condition } \\
\text { Survey }\end{array}$ & & & \\
\hline
\end{tabular}

\section{Table A2}

Methods employed by surveys

\begin{tabular}{|c|c|c|c|c|}
\hline Department & Survey & $\begin{array}{l}\text { Disaggregated by impairment / } \\
\text { capability }\end{array}$ & Open ended question or list? & Method of data collection \\
\hline Culture, Media and Sport & Taking Part Survey & Yes & List - capabilities & Face-to-face \\
\hline Transport & National Travel Survey & No & & Face-to-face \\
\hline \multirow{2}{*}{$\begin{array}{l}\text { Communities and Local } \\
\text { Government }\end{array}$} & English Housing Survey & Yes & List - impairment & Face-to-face \\
\hline & New Place Survey & Yes & List - capabilities & Postal survey \\
\hline \multirow{3}{*}{ Children, Schools and Families } & Youth Cohort Study & No & & Face-to-face \\
\hline & $\begin{array}{l}\text { 18-19 - Longitudinal Study of } \\
\text { Young People in England }\end{array}$ & Yes & Open plus list - capabilities & Face-to-face \\
\hline & $\begin{array}{l}\text { Post } 16 \text { National Pupil Database } \\
\text { and Individual Learner Record }\end{array}$ & Yes & $\begin{array}{l}\text { List - impairment plus a specific } \\
\text { list about learning difficulty }\end{array}$ & $\begin{array}{l}\text { School census face-to-face with } \\
\text { Special Educational Needs adviser }\end{array}$ \\
\hline \multirow{3}{*}{ Welsh Assembly } & Welsh Health Survey & No & & $\begin{array}{l}\text { Short face-to-face interview } \\
\text { followed by a detailed self } \\
\text { completion questionnaire }\end{array}$ \\
\hline & Living in Wales & Limited information & Open & Face-to-face \\
\hline & Future Skills Wales & No & & Face-to-face \\
\hline Work and Pensions & Family Resources Survey & Yes & List - capabilities & Face-to-face \\
\hline \multirow{5}{*}{ Office for National Statistics } & $\begin{array}{l}\text { Integrated Household Survey; } \\
\text { Expenditure and Food Survey; } \\
\text { Survey of English Housing }\end{array}$ & No & & $\begin{array}{l}\text { Face-to-face and telephone } \\
\text { interview }\end{array}$ \\
\hline & $\begin{array}{l}\text { General Household Survey and EU- } \\
\text { SILC Minimum European Health } \\
\text { Module }\end{array}$ & Yes & Open & $\begin{array}{l}\text { Face-to-face and telephone } \\
\text { interview }\end{array}$ \\
\hline & Opinions Survey & Yes & List - capabilities and impairment & $\begin{array}{l}\text { Face-to-face and telephone } \\
\text { interview }\end{array}$ \\
\hline & Household Assets Survey & Yes & List - capabilities & $\begin{array}{l}\text { Face-to-face and telephone } \\
\text { interview }\end{array}$ \\
\hline & Labour Force Survey & Yes & List - impairments & $\begin{array}{l}\text { Face-to-face and telephone } \\
\text { interview }\end{array}$ \\
\hline
\end{tabular}


Table A2

continued

Methods employed by surveys

\begin{tabular}{|c|c|c|c|c|}
\hline Department & Survey & $\begin{array}{l}\text { Disaggregated by } \\
\text { impairment/capability }\end{array}$ & Open ended question or list? & Method of data collection \\
\hline $\begin{array}{l}\text { Business Enterprise and } \\
\text { Regulatory Reform }\end{array}$ & Fair Treatment at Work & No & & Face-to-face \\
\hline \multirow{3}{*}{ Scottish Government } & Health Survey & Yes & Open & Computer aided interview - face-to-face \\
\hline & All Forests Visitor Monitoring Survey & Yes & List - impairment & Face-to-face \\
\hline & Scottish House Condition Survey & Yes & List-impairment & Computer aided interview - face-to-face \\
\hline \multirow{3}{*}{ Northern Ireland } & Census & No & & Face-to-face \\
\hline & Continuous Household Survey & Yes & Open & Face-to-face \\
\hline & Health and Social Wellbeing Survey & Yes & Open & Face-to-face \\
\hline \multirow{3}{*}{$\begin{array}{l}\text { Innovation, Universities } \\
\text { and Skills }\end{array}$} & Higher Education Statistics Agency & Yes & List-impairment & Application form \\
\hline & Student Income and Expenditure Survey & No & & Face-to-face \\
\hline & Universities and Colleges Admission Service & Yes & List-impairment & Application form \\
\hline
\end{tabular}

